\title{
A COMPARISON BETWEEN 1D ELECTROMAGNETIC MODELING PROGRAMS: A CASE HISTORY FOR CRISTALINO IRON OXIDE COPPER GOLD DEPOSIT, CARAJÁS MINERAL PROVINCE, BRAZIL
}

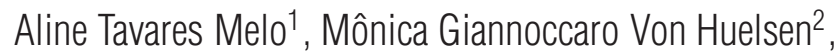 \\ Umberto José Travaglia Filho ${ }^{3}$ and Reinhardt Fuck ${ }^{4}$
}

\begin{abstract}
Cristalino (482 Mt @ 0.65\% Cu and $0.06 \mathrm{~g} / \mathrm{t} \mathrm{Au}$ ) is a world class Cu-Au IOCG deposit located in the Carajás Mineral Province, Brazil. As extensive overburden cover makes exposure of the bedrock limited in Carajás region, geophysics plays a fundamental role in exploration. Detailed understanding of the geophysical signature of the known deposits is the key for future exploration as the targets are getting deeper. Two methods were applied to the 1D electromagnetic inversion (ImagEM and EM1DTM programs) and 2.5D plate modeling (Maxwell program). The inversion results for Cristalino show that even if the deposit is not massive sulfide, it was effectively modeled and the methods respond very well to the ore body. The electromagnetic signature of the deposit obtained by the plate modeling is of $21 \mathrm{~S}$ for the high-grade ore and $15 \mathrm{~S}$ for the low-grade ore, and a new target was identified to the south of the main deposit. The anomalous body obtained by EM1DTM has the resistivity of 660 0hm.m. Even though ImagEM is not quantitatively accurate, it can map the resistivity contrast with good precision.
\end{abstract}

Keywords: electromagnetic modeling, Carajás, mineral exploration.

RESUMO. Cristalino (482 Mt @ 0,65\% Cu e 0,06 g/t Au), localizado na Província Mineral de Carajás, Brasil, é um depósito IOCG de Cu-Au de classe mundial. Como a extensa cobertura de solo limita a exposição de rocha não-intemperizada na região de Carajás, a geofísica se torna fundamental na exploração mineral. A compreensão detalhada da assinatura geofísica de depósitos conhecidos é a chave para o futuro da exploração, pois os alvos estão ficando cada vez mais profundos. Para este trabalho, dois métodos foram aplicados para a inversão eletromagnética 1D (programas ImagEM e EM1DTM) e modelo de placas 2,5D (programa Maxwell). Os resultados das inversões para Cristalino mostram que mesmo não sendo de sulfeto maciço, o depósito foi modelado de forma eficiente e que o método responde muito bem ao corpo de minério. A assinatura eletromagnética do depósito, obtida pelo modelo de placas, é de 21S para o minério de alto teor e $15 \mathrm{~S}$ para o minério de baixo teor, e um novo alvo foi identificado a sul do depósito principal. 0 corpo anômalo obtido pelo EM1DTM tem resistividade de 660 Ohm.m. Mesmo que ImagEM não tenha acurácia quantitativa, pode mapear o contraste de resistividade com precisão muito boa.

Palavras-chave: modelagem eletromagnética, Carajás, exploração mineral.

\footnotetext{
${ }^{1}$ Universidade Federal de Minas Gerais, Instituto de Geociências, Departamento de Geologia, Avenida Antônio Carlos, 6.627, Pampulha, 31270-901 Belo Horizonte, MG, Brazil. Phone: +55(31) 3409-3792; Fax: +55(31) 3409-5424 - E-mail: alinetmcs@gmail.com

2Universidade de Brasília, Instituto de Geociências, Campus Universitário Darcy Ribeiro, Asa Norte, 70910-900 Brasília, DF, Brazil. Phone: +55(61) 3349-4453 Ramal: 2145; Fax: +55(61) 3107-1297 - E-mail: monicavon.huelsen@gmail.com

3Universidade de Brasília, Observatório Sismológico, Campus Universitário Darcy Ribeiro, Asa Norte, 70910-900 Brasília, DF, Brazil. Phone: +55(61) 3340-4055; Fax: +55(61) 3107-1297 - E-mail: beto_tt@yahoo.com.b

${ }^{4}$ Universidade de Brasília, Instituto de Geociências, Campus Universitário Darcy Ribeiro, Asa Norte, 70910-900 Brasília, DF, Brazil. Phone: +55(61) 3307-1018 - E-mail: reinhardt@unb.br
} 


\section{INTRODUCTION}

The class of Iron Oxide Copper-Gold (IOCG) deposits has captured the attention of many mineral explorers in the last decades since the discovery of the giant Olympic Dam breccia-hosted iron oxide Cu-Au-U-REE deposit in South Australia (Smith, 2002). There have been notable successes, and extensive exploration programs continue on most continents (Smith, 2002). They are often localized along fault splays of major, crustal scale extensional faults, but are located in diverse rock types, resulting in a wide variety of deposit styles and mineralogies (Hitzman, 2000).

The essential criteria are that IOCG deposits are formed by magmatic-hydrothermal processes, have $\mathrm{Cu} \pm \mathrm{Au}$ as economic metals, and are structurally controlled - commonly with breccias (Groves et al., 2010). The primary mineralogical characteristic of all deposits in this class is the abundance of magmatically sourced iron oxide, either magnetite or hematite. The presence of copper, as chalcopyrite is a primary economic characteristic. Due to the large influence of structural control, deposits of this type occur in many shapes, sizes and attitudes (Hitzman, 2000).

Cristalino (482 Mt @ 0.65\% Cu and 0.06 g/t Au, NCL Brasil, 2005) is a world class IOCG deposit located in the Carajás Mineral Province, a highly mineralised metallogenic region. The Province has been long recognized for its giant enriched iron and manganese deposits, but over the past 20 years has been increasingly acknowledged as one of the most important $\mathrm{Cu}-\mathrm{Au}$ and $\mathrm{Au}-$ PGE provinces globally, with deposits extending along an approximately $150 \mathrm{~km}$ long WNW-trending zone about $60 \mathrm{~km}$ wide centred on the Carajás Fault. The larger deposits (approx. 2001000 Mt @ 0.95-1.4\% Cu and 0.3-0.85 g/t Au) are classic Feoxide Cu-Au deposits that include Salobo, Igarapé Bahia-Alemão, Cristalino and Sossego (Grainger et al., 2008).

Extensive overburden cover makes exposure of the bedrock limited in Carajás region. This has resulted in a limited understanding of the regional geology and it hampers exploration for IOCG deposits. Geophysical methods have been applied in order to improve the regional geology and search for sulphide deposits underlying the overburden. The detailed understanding of the geophysical signature of the known deposits is the key for future exploration as the targets are getting deeper and they can be located at any part of the main fault and its splays. This work shows the result of inversion of electromagnetic data over an IOCG deposit searching for the electromagnetic signature of the deposit.

\section{GEOLOGICAL SETTING}

The Cristalino Cu-Au Deposit is located in the Carajás Neoarchean Domain, also known as Itacaiunas Belt, southeastern Amazonian Craton (Docegeo, 1988; Huhn et al., 1988) (Fig. 1).
Cristalino Deposit is hosted by a splay of the Carajás fault located in the southeastern part of Carajás Neoarchean Domain (Fig. 1b). Its Cu-Au mineralization is hosted by hydrothermally altered mafic to felsic volcanic rocks interlayered with iron formation of a volcano-sedimentary sequence and was classified as an IOCG (Fe-Cu-Au-U-REE) deposit type. Granite, diorite and quartz-diorite intrude the volcano-sedimentary sequence (Fig. 2; Huhn et al., 1999).

The deposit is estimated at $482 \mathrm{Mt} @ 0.65 \% \mathrm{Cu}$ and $0.06 \mathrm{~g} / \mathrm{t}$ Au (NCL Brasil, 2005). The mineralization occurs in stockwork, stringer, breccias, disseminated in the host rock and filling fractures that cut the sequence. The main ore minerals are chalcopyrite and gold (Huhn et al., 1999). The geological model built from drilling information, as logging and assay, divided the ore body in high-grade and low-grade bodies (Fig. 3).

\section{MODELING PROGRAMS}

The electromagnetic time-domain (TDEM) methods are very important for exploration of massive to semi-massive sulfide deposits. The area of Cristalino was covered by a ground TDEM survey aiming to identify the high conductivity zones (chalcopyrite + hydrothermal magnetite).

The electromagnetic data set at Cristalino was inverted by using approaches in inverse theory as described by Oldenburg \& $\mathrm{Li}$ (2007). The earth is discretized into a large number of rectangular cells of constant physical properties and whose size is smaller than the resolution of the survey. The aim of the inversion algorithm is to construct the simplest model that adequately reproduces the observations. To confront the nonuniquess, the inverse problem is formulated to minimize an objective function of the model subject to adequately fit the data.

The ground electromagnetic (EM) data have been forward modeled using the software Maxwell from EMIT (ElectroMagnetic Imaging Technology, 2011) and inverted using two different 1D algorithms, the EM1DTM 1.0 from UBC (University of British Columbia) (Farquharson, 2006) and the ImagEM, under development by UnB (Universidade de Brasília) (Travaglia Filho, 2012).

The plate forward modeling was important to define plate size, azimuth and dip, which adequately fits the data. The EM1DTM program allows the use of a wide set of transmitter/receiver configuration, waveforms and time windows to give an electrical conductivity model. The earth models are composed of layers of uniform conductivity with fixed interface depths. The value of the conductivity in each layer is sought by the inversion. Each sounding is inverted independently for a one-dimensional model under the sounding location, these can be viewed directly as a composite 


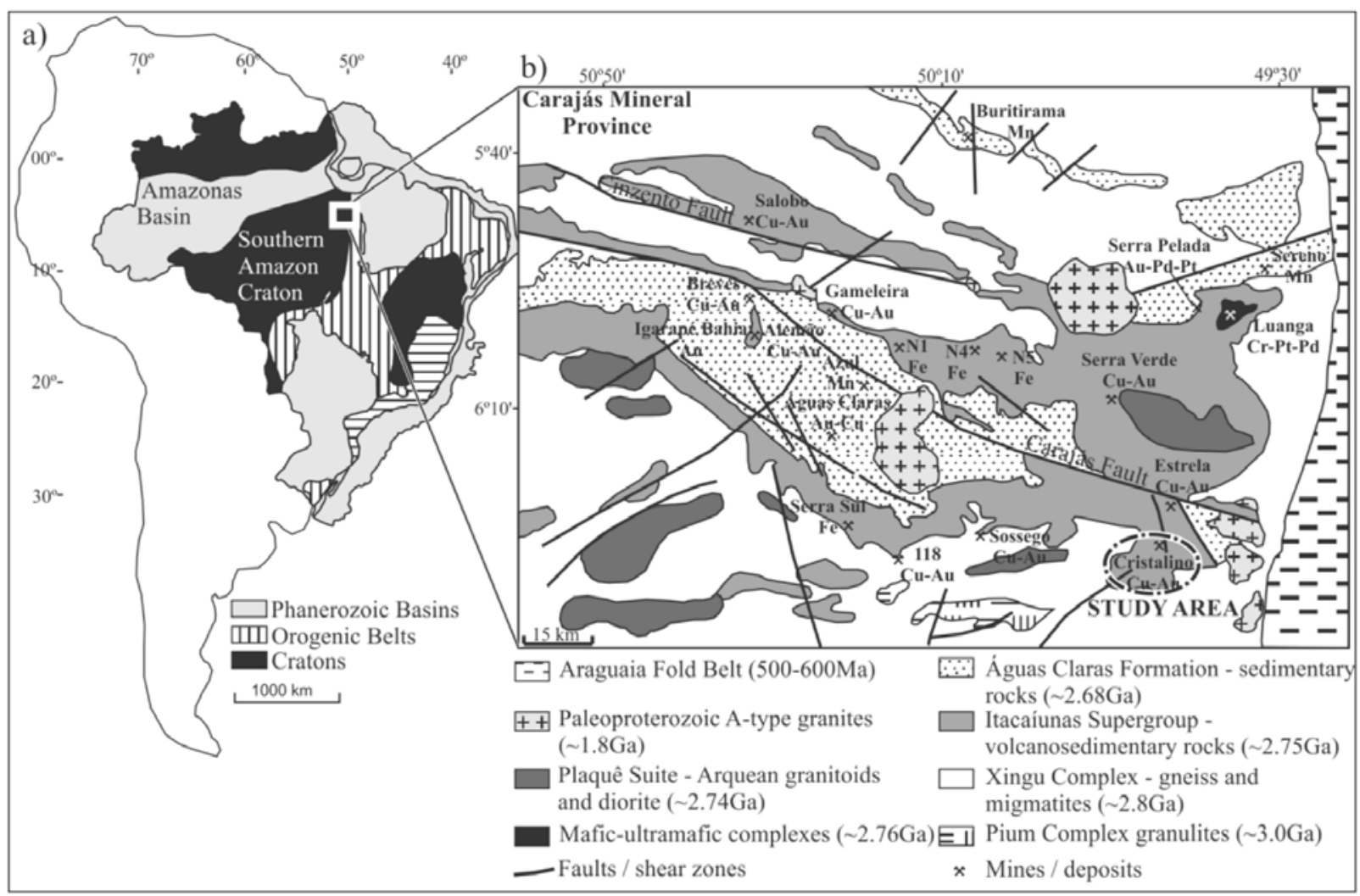

Figure 1 - (a) Tectonic location of the Carajás Mineral Province at the southeastern margin of the Southern Amazonian craton, Brazil (Almeida et al., 1981); (b) Geologic Map of the Carajás Mineral Province showing the study area (Docegeo, 1988; Grainger et al., 2008).

two-dimensional image for the whole line. The Huber M-measure is used for data misfit and Ekblom p-measure for model structure, which allow for a whole suite of variations, from the traditional sum-of-squares measures, to more robust measures which can ignore outliers in the observations and which can generate piecewise-constant models (Farquharson \& Oldenburg, 1998). Four possible methods for determining the degree of regularization are possible:

(1) the trade-off parameter is specified by the user, either as a single constant value, or with a cooling schedule to some final value;

(2) the trade-off parameter is automatically chosen to achieve a user-supplied target misfit;

(3) the trade-off parameter is automatically chosen using the GCV (generalized cross-validation) criterion; or

(4) the trade-off parameter is automatically chosen using the L-curve criterion (Farquharson, 2006).
The ImagEM was initially based on the RAMPRES program (Sandberg, 1988; Von Huelsen, 2007), the program works for in-loop configuration when the receiver coil is concentric to the transmitter coil. It calculates the apparent resistivity applying the secant method and does not take any a priori information (Travaglia Filho, 2012).

The formulation is from Frischknecht \& Raab (1984), it first calculates the resistivity for each measured time channel using different equations for early and late time, and then it takes the result to find the apparent resistivity through secant method with many numbers of iterations for each channel.

For the channels the user defines as early time, the program applies the Eq. (1):

$$
\rho_{E T}=\frac{r_{T}^{3} \frac{d B_{z}}{d t}}{3 a_{r}}
$$

$\rho_{E T}=$ resistivity of early time channels, $r_{T}=$ transmitter radius, $d B_{z} / d t=$ the electromagnetic field decay in $Z$ direction measured in the equipment, and $a_{r}=$ effective area of the receiver. 


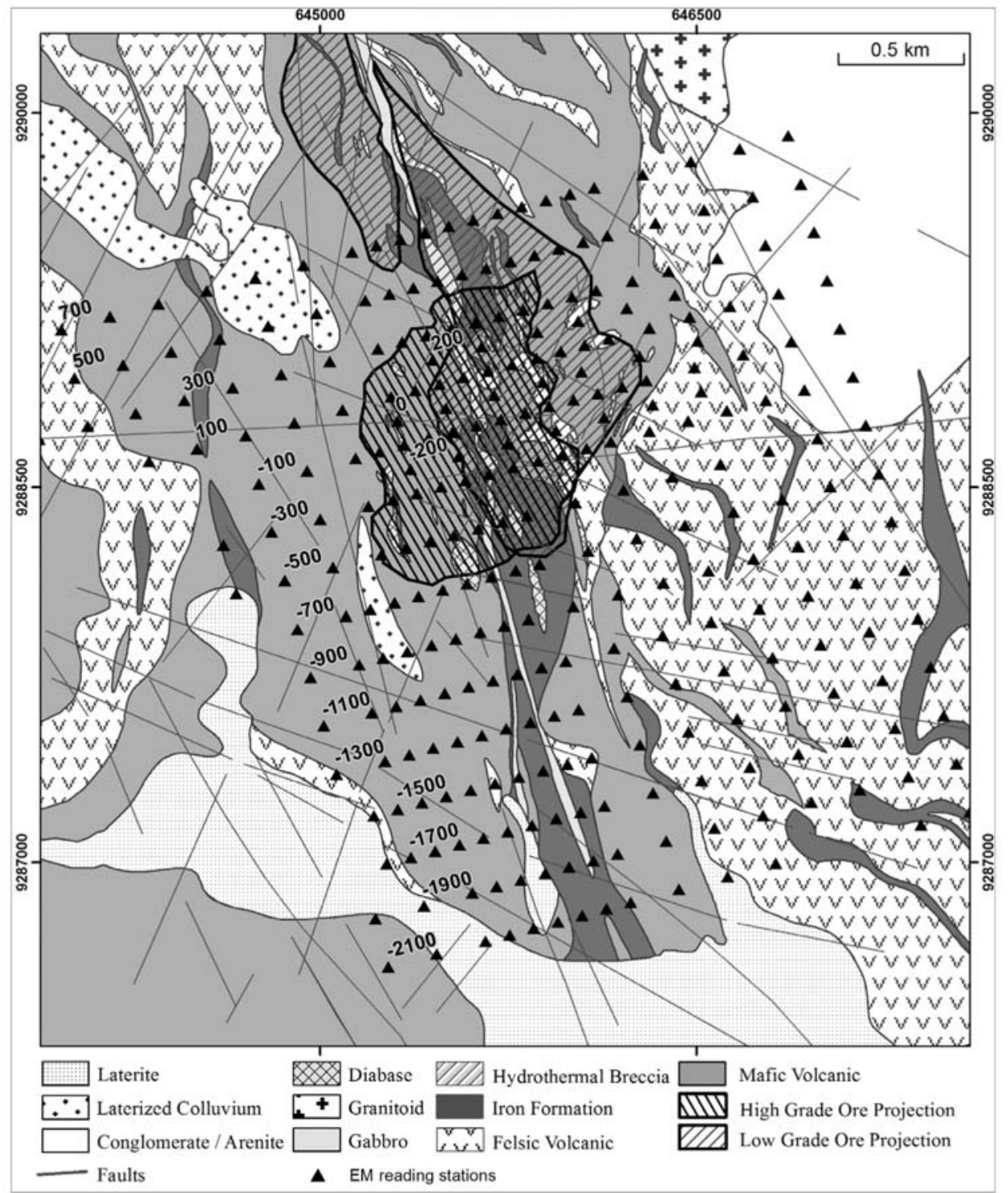

Figure 2 - Lithological map of Cristalino Cu-Au Deposit showing the EM reading stations (Vale, 2004).

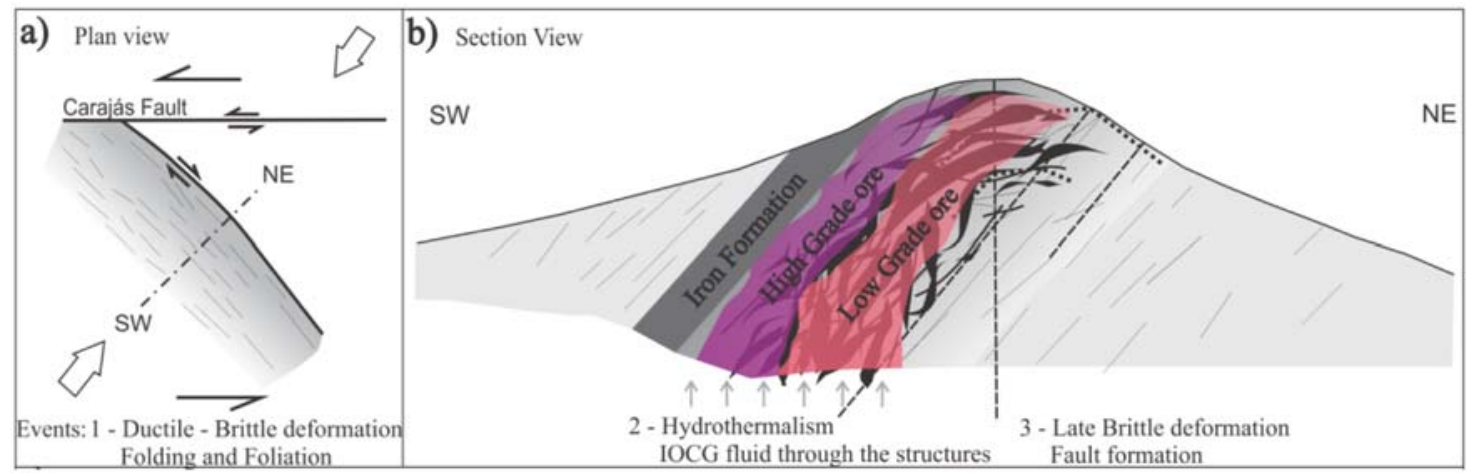

Figure 3 - (a) Schematic plan view of Cristalino area showing the faults and direction of deformation, (b) Schematic geological section showing the hydrothermal mineralized zone and the events that formed the deposit (Adapted from Pinheiro, 2000). 
For the late time channels, when the secondary field is smaller, the program applies the Eq. (2) for each channel:

$$
\rho_{L T}=\frac{\mu_{0}}{4 \pi t_{n}}\left(\frac{4 \mu_{0} T m}{t \frac{d B_{z}}{d t}}\right)
$$

$\rho_{L T}=$ resistivity of late time channels, $\mu_{0}=$ magnetic permeability of free space, $T m=$ transmitter dipole moment, and $t_{n}=$ time at channel $n$ ( $n$ depends on the number of channels of the system).

The next step is to take the calculated $\rho$ and apply in the Eq. (3):

$$
\rho_{a_{n}}=\frac{\left(\frac{\mu_{0} r_{T} a_{r} 0.886226}{\delta a_{T}}\right)(1-2 R)\left[\left(\frac{\mu_{0} r_{T}^{2}}{t_{n} x}\right)^{k+1.5}-\left(\frac{\mu_{0} r_{T}^{2}}{t_{n}+\delta x}\right)^{k+1.5}\right]}{4^{k} k !(2 k+5)(2 k+3)}
$$

$\rho_{a_{n}}=$ apparent resistivity of layer $n$ (the number of layers is equal the number of channels), $\delta=$ ramp turn-off time, $a_{T}=$ transmitter coil area, $k$ = number of the iteration, $R=$ the difference of the division $k / 2$, and $x=\log \rho$ (for the early time channels is $\log \rho_{E T}$ and for late time channels $\log \rho_{L T}$ ). This equation can reach up to 70 iterations using the secant method and is applied to every channel. At this point, the program has 20 values of apparent resistivity, the last part is to find the depth associated to each one.

There are many ways of calculating depth associated to a secondary electromagnetic field. The program ImagEM uses a formulation form Eaton (1989):

$$
d_{n}=150 \sqrt{t_{n} \rho_{a_{n}}}
$$

$d_{n}=$ depth of layer $n$ (the number of layers is equal the number of channels).

Each sounding is inverted independently for a one-dimensional model under the sounding location, with the sequence of onedimensional models written out, these can be viewed directly as a composite two-dimensional image.

\section{SURVEY DATA AND PROCESSING}

The deposit area was covered by a detailed ground survey according to the specifications of Table 1.

The ground EM data were acquired using the PROTEM 57 equipment, moving loop, centre in-loop readings $X, Y$ and $Z$ components, measuring $\mathrm{dB} / \mathrm{dt}$, current of $8 \mathrm{~A}, 20$ time channels, loop side of $200 \times 200 \mathrm{~m}$, at the stations shown by Figure 2 . The image of $Z$ component channel 05 (Fig. 4a) shows three anomalies of high amplitude, where the anomaly in the west of highest amplitude is due to the Laterized Colluvium. The central anomaly is the deposit and the anomaly to the south has the same signature of the deposit.

The anomaly corresponding to the conductive overburden decreases until it no longer appears after channel 10 of the $Z$ component, and the anomalies corresponding to the mineralized zone have its area increased with increasing depth (Figs. 4b,c,d), being strongly associated to the high-grade ore which was modeled using the information of more than 300 drill holes. An interesting feature is that the anomaly is not homogeneous (it has higher amplitude zones inside the deposit area), reflecting the ore texture that varies between stockwork, stringer, breccia and disseminated, therefore varying its connectivity.
In electromagnetic methods the decay analysis is the most important tool for ranking the targets. The profile analysis (Fig. 5) shows that the deposit has a very strong effect of the overburden, but in the late channels, the decay is slow.

\section{RESULTS}

\section{Forward model}

A plate model was built for the ground TDEM data using the EMIT Maxwell 5.3.4.9713 software. Only channels 10 to 20 were considered for this model because of the strong overburden response of channels 01 to 09 . The plate model aims to fit all three components and it is very accurate for dip, azimuth and extents.

The plate model delineates the general framework of the deposit and the modeled conductivities vary from 3 to 21 Siemens (Fig. 6a). Considering that the mineralization style is not massive but instead a mixture of styles, the modeled plates are not interpreted as single layers of massive sulfide, but as the average of the sum of the response of all styles in the mineralized zone. Figure $6 b$ shows that the best plate (line - 300, 21 Siemens) maps the top of the high-grade ore having the same dip of this zone. 
Table 1 - Geophysical survey specifications over Cristalino Deposit.

\begin{tabular}{|c|c|c|c|c|c|c|}
\hline System & Company & Configuration & $\begin{array}{c}\text { Line } \\
\text { spacing }\end{array}$ & $\begin{array}{c}\text { Station } \\
\text { spacing }\end{array}$ & Year & $\begin{array}{c}\text { Other } \\
\text { specification }\end{array}$ \\
\hline PROTEM & Geomag & N75E lines & $100-200 \mathrm{~m}$ & $100-200 \mathrm{~m}$ & 1999 & PROTEM $57,30 \mathrm{~Hz}$ \\
\hline
\end{tabular}
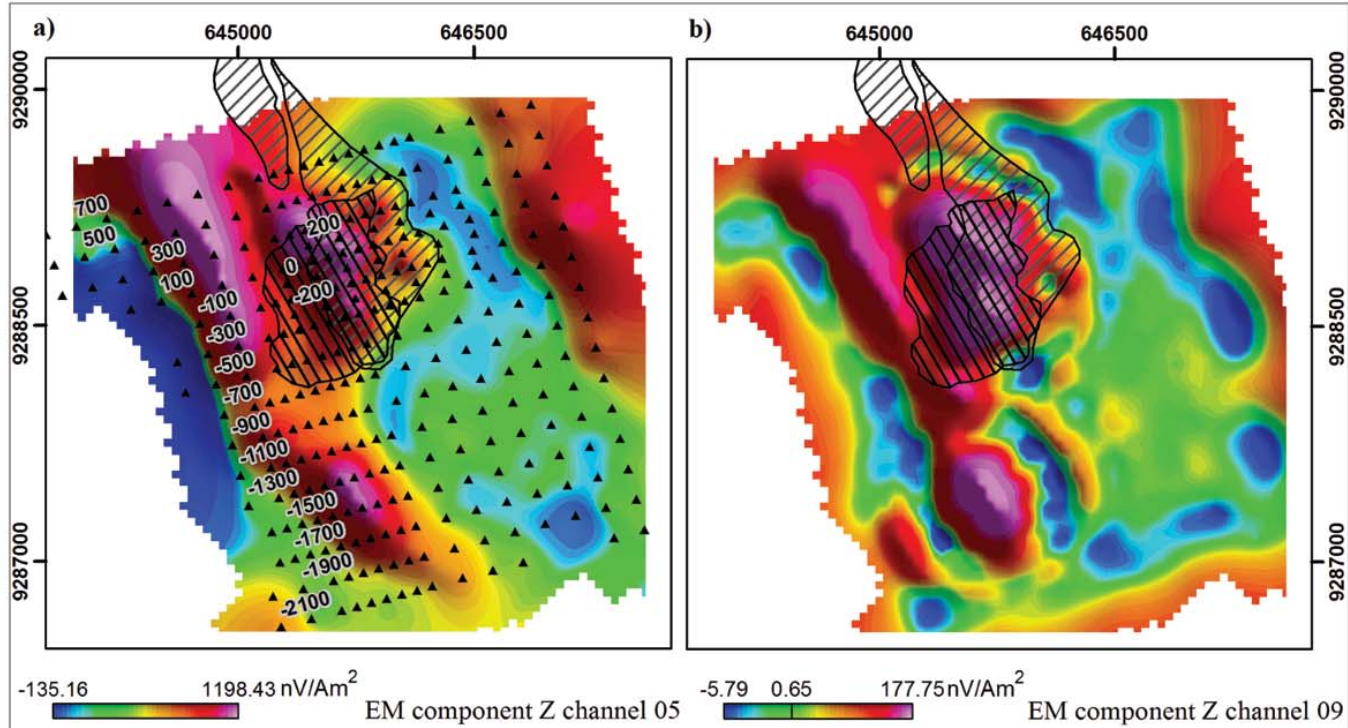

c)

:

d)

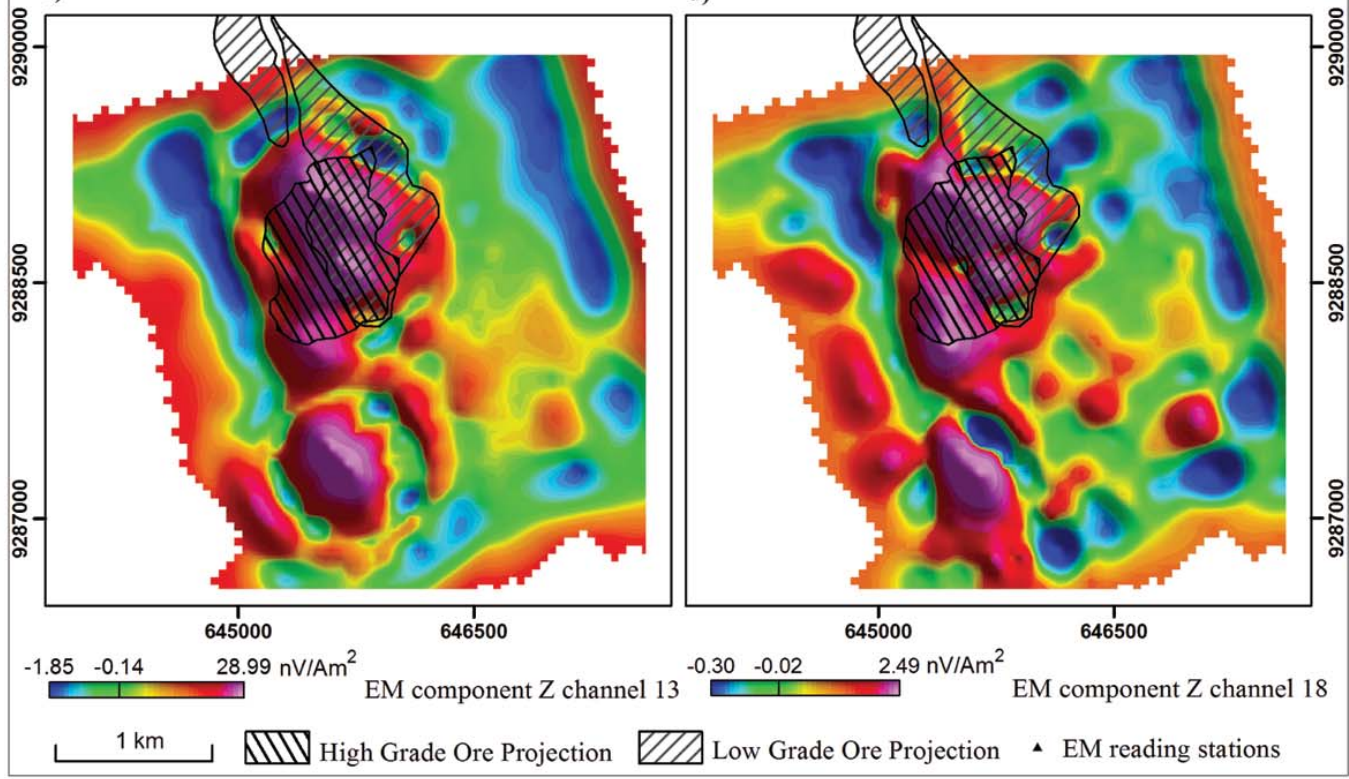

Figure 4 - (a) Image of the ground electromagnetic component $Z$ channel 05; (b) Image of the ground electromagnetic component $Z$ channel 09; (c) Image of the ground electromagnetic component $Z$ channel 13; and (d) Image of the ground electromagnetic component $Z$ channel 18 .

Plate of line 500 (18 Siemens) also seems to map the top of the low-grade ore with a slight change in the azimuth in relation to the previous plate, reflecting the change in azimuth of the lowgrade ore that trends more to northwest.
The weaker plates are related to the iron formation bed (Fig. 6c). As observed in the EM images of the previous section, there is an anomaly to the south of the deposit that is associated to a 15 Siemens plate (line -1500). It trends approximately east- 


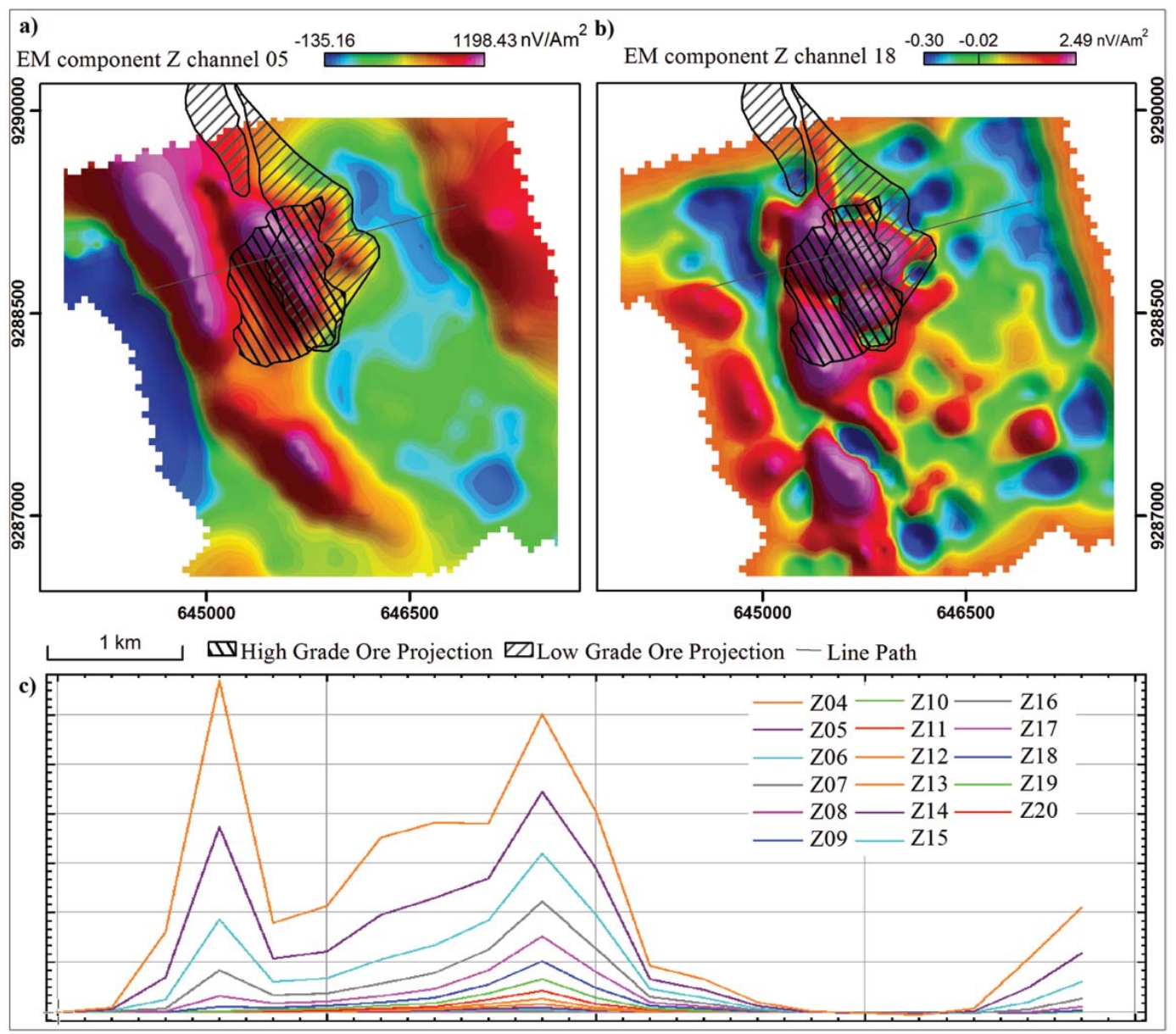

Figure 5 - (a) Image of the ground electromagnetic component $Z$ channel 05; (b) Image of the ground electromagnetic component $Z$ channel 18; and (c) profile of channels 04 to 20 of the $Z$ component showing the overburden to the left and the deposit response to the right.

west, a different azimuth of the deposit and the two drill holes in the region do not intercept significant mineralization. The holes there are almost parallel to the plate and could have missed the target (Fig. 6d).

\section{Inversion}

The EM1DTM inversion behaved well for every station, where Phi d (misfit) decreased, Phi m (model norm) increased every iteration and observed data are of the same order of magnitude of the predicted data. For data misfit Huber norm was used because it is a robust misfit measurement that is less influenced by outliers. The inversion type used was the fixed trade-off cooling schedule, where it starts with a large trade-off parameter and reduces it in every iteration. For the model norm the alpha-s was lowered and alpha-z raised to force the model to be smoother. The starting model that was used went to 4000 meters using 100 layers at 6000 Ohm.m. This model was used as both the starting model and the reference model for all soundings. Each sounding was inverted independently for a one-dimensional model under the sounding location; the resistivity values of the layers under the soundings were gridded into a two-dimensional section of $50 \times 50 \mathrm{~m}$ and into a three-dimensional mesh of $50 \times 50 \times 50 \mathrm{~m}$ cell size.

Figure 7a shows the low resistivity body obtained (660 Ohm.m), it has a very good fit with the high-grade ore extents and with high + low-grade ore thickness (Figs. 7a,b).

As the ImagEM output is not quantitative but instead a qualitative result focused on showing the anomalous region, the resistivity values are going to be referred as low or high. Each sounding was inverted independently for a one-dimensional model under the sounding location. The recovered resistivity values of the layers under the soundings were gridded into a two-dimensional section of $50 \times 50 \mathrm{~m}$ and into a three-dimensional mesh of $50 \times 50 \times 50 \mathrm{~m}$ cell size 


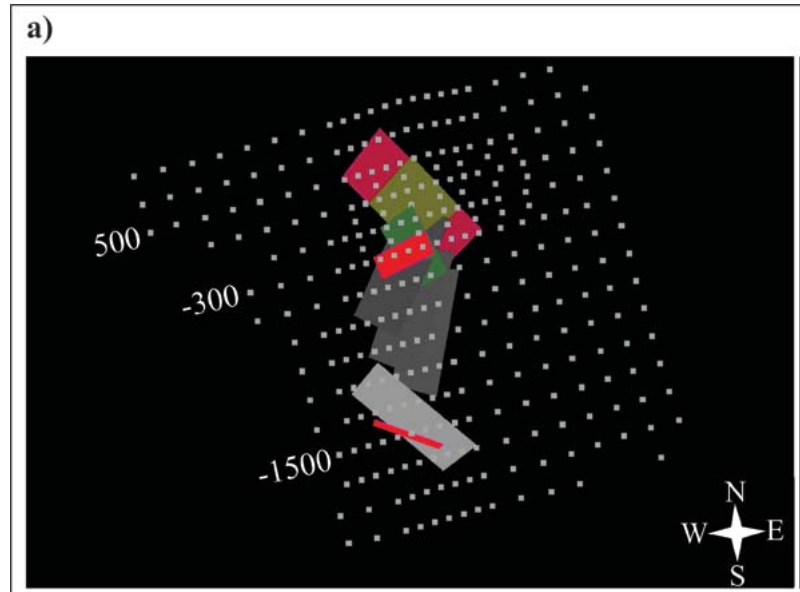

b)

c)
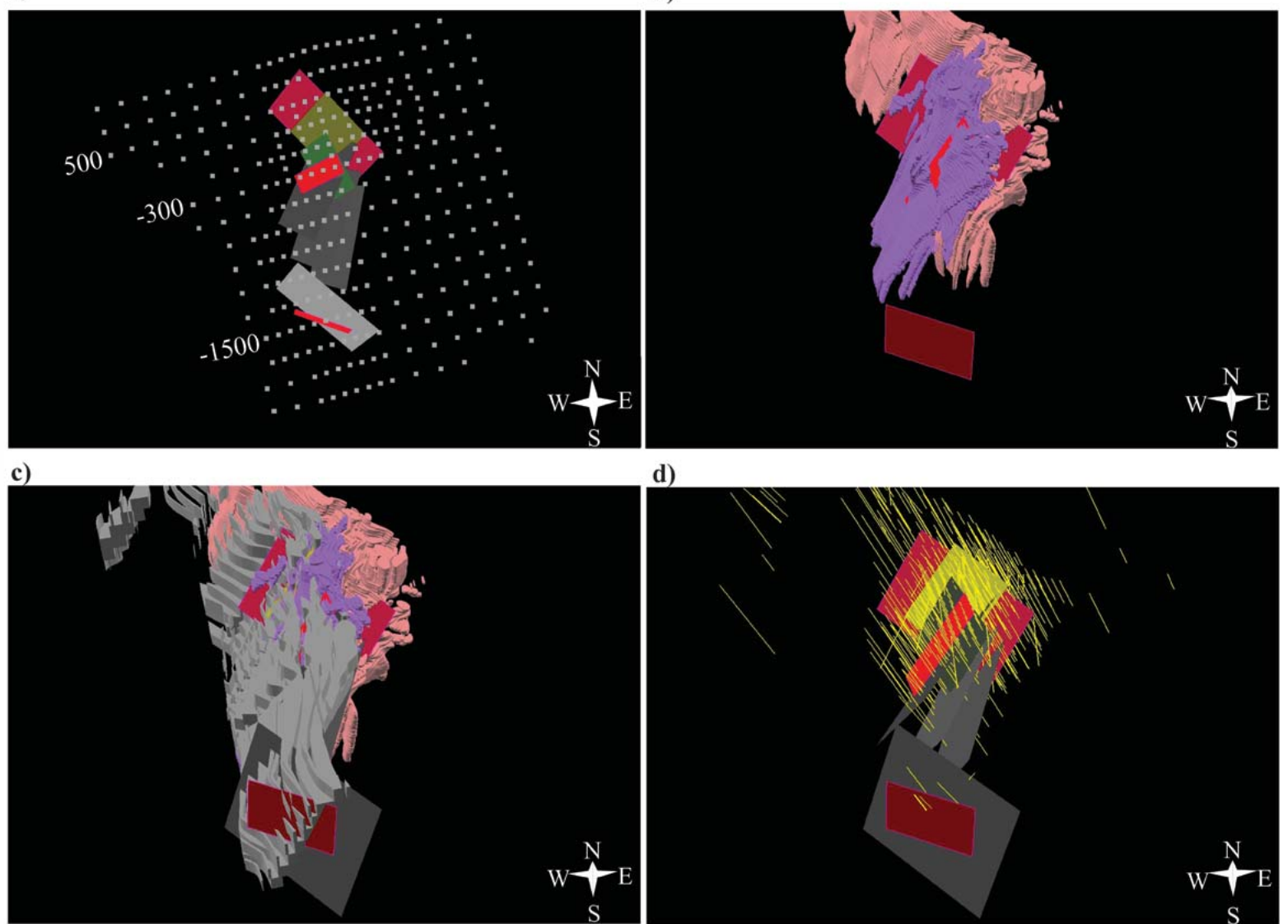

d)
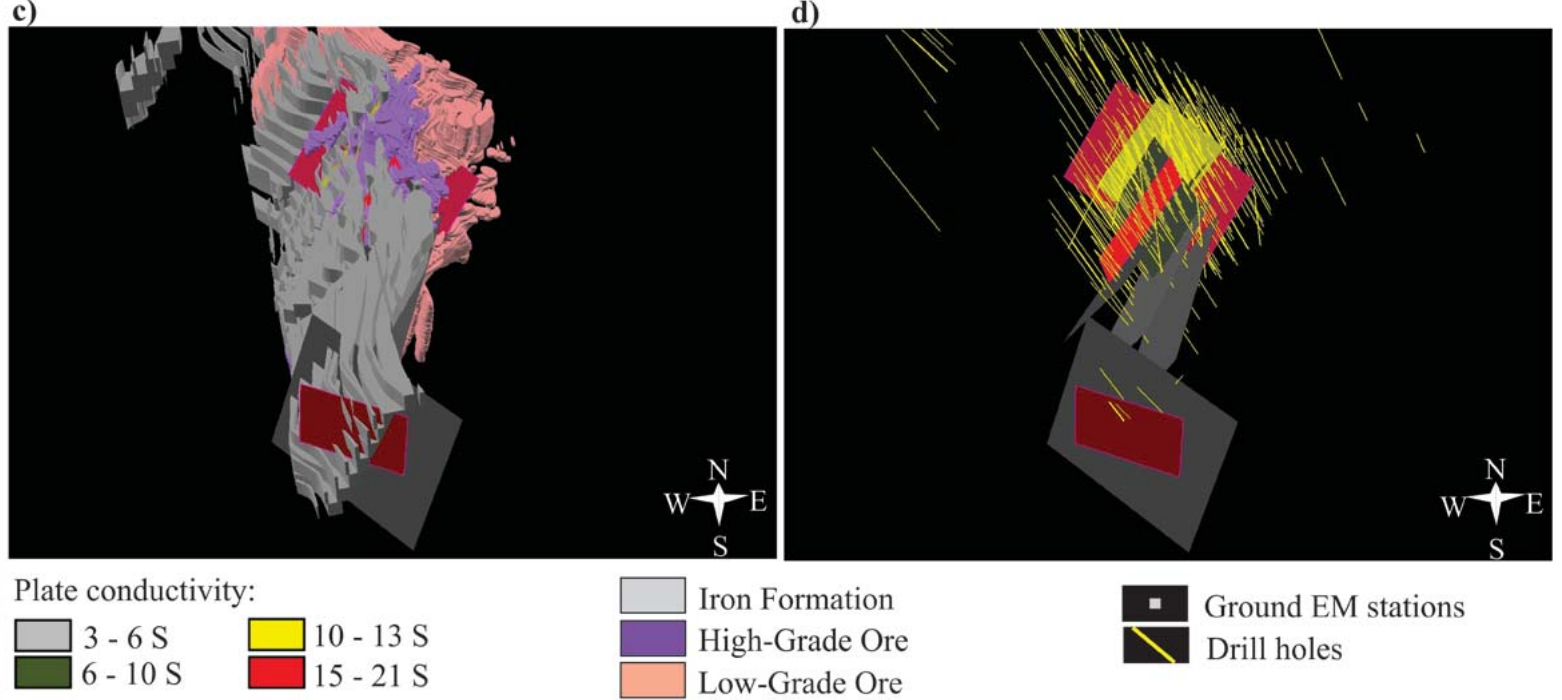

Plate conductivity:

$6-10 \mathrm{~S}$

$15-21 \mathrm{~S}$

Iron Formation

High-Grade Ore

Low-Grade Ore Ground EM stations
Drill holes

Figure 6 - (a) Ground EM stations and the modeled plates; (b) the best conductivity plates with the high- and low-grade ore; (c) the plates with the high- and low-grade ore and the iron formation; and (d) the plates with all drill holes of the deposit.

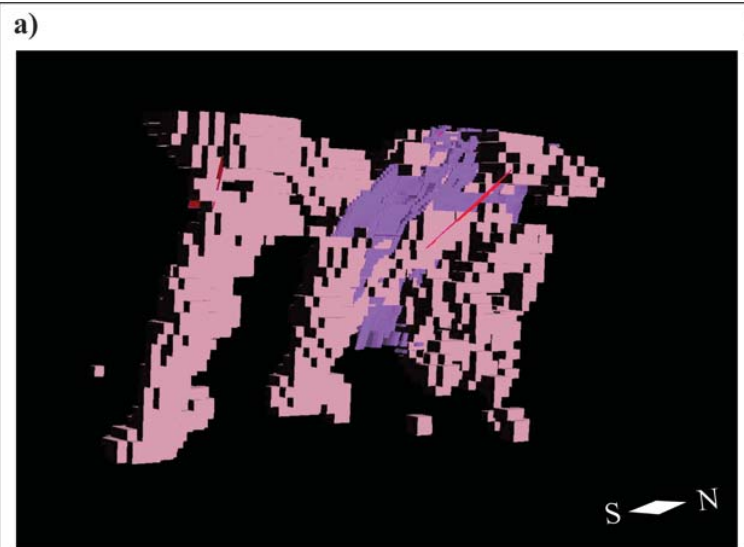

EM1DTM 1D inversion b)

High-Grade Ore

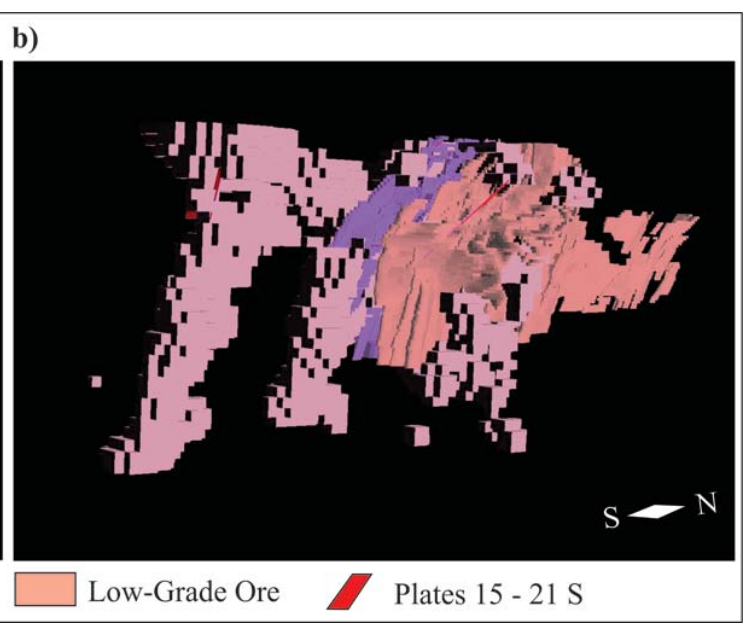

Figure 7 - (a) Cut-off of 660 0hm.m body with the high-grade ore; and (b) Cut-off of 660 Ohm.m body with the high-grade and low-grade ore. 


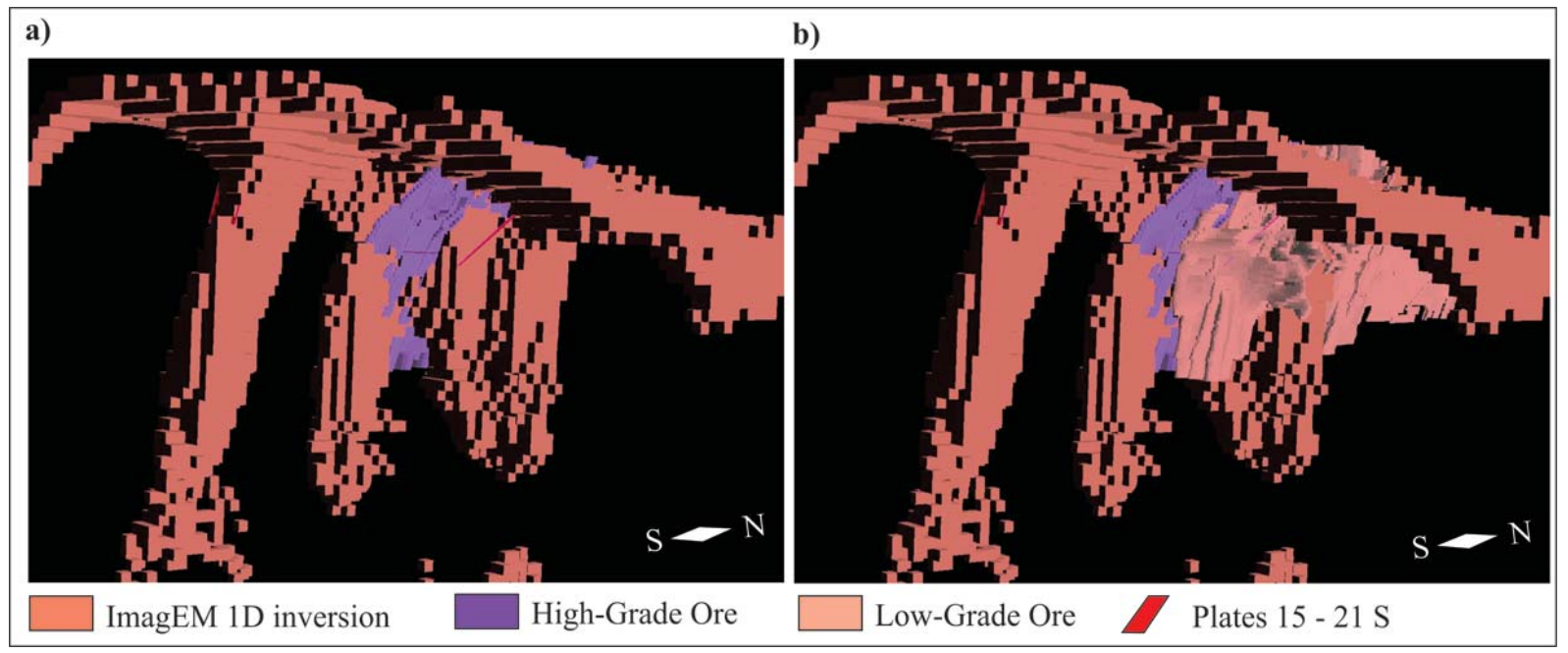

Figure 8 - (a) Low resistivity body with the high-grade ore; and (b) Low resistivity body with the high-grade and low-grade ore.

Figure 8a shows the main low resistivity body of the inversion, the overburden was well and continuously modeled. The main part of the model is spatially coincident with the high-grade ore (Fig. 8b) and does a good job on mapping its lateral extents but the dip is vertical, while the high-grade ore is west dipping. However, the $Z$ component is the only one considered for the inversion.

The low resistivity body has the thickness very similar to the thickness of the orebody, high- and low-grade (Fig. 8b) meaning that the model could pick the response of both. Although the body is continuous at shallower depths, it splits into two when it gets deeper. This deeper part of the deposit was not drilled yet but this information can be used as a guide to focus the drilling where the model indicates the ore is continuous. The anomaly to the south of the deposit (15S plate and 660 Ohm.m) shows up as a very consistent low resistivity body, as deep as the deposit but much narrower.

The result of the $1 \mathrm{D}$ inversion using EM1DTM is identical to the result of ImagEM. Although EM1DTM gives more detailed structures, it can be observed that the overburden response was not continuously modeled as in the ImagEM model.

\section{DISCUSSION AND CONCLUSIONS}

Accurately differentiating bedrock conductor from overburden conductors is one of the major strategies that have to be followed for metal exploration in the Amazon region. The inversion results for Cristalino show that even if the deposit is not massive sulfide, it was effectively modeled and the methods respond very well to the ore body, especially to the high-grade ore. All electromagnetic models could map its northern and southern extents with good accuracy. The electromagnetic signature of the deposit obtained by the plate modeling is $21 \mathrm{~S}$ for the high-grade ore and $15 \mathrm{~S}$ for the low-grade ore.

When comparing the EM modeling processes it can be seen that Maxwell is very sensitive to the experience of the user. Thus, the model can be variable from user to user and depending on the complexity of the data, it takes one day to model each survey line. Even though the target in this case study is not massive mineralization, Maxwell does a very good job on mapping the ore zone. However, this work evidences that integration with other data shows that if the drill holes are planned just considering the plate model, the best part of the target can be missed, considering that the most conductive plate in Cristalino is at the top of the highgrade ore zone.

EM1DTM program also depends a lot on the experience of the user on inversion and on the software configuration to find the best parameters for the dataset that is being used. One advantage is that the program accepts all kinds of survey configuration but the input data format the program requires takes a long time from the user to get the data ready.

ImagEM uses a format similar to the one delivered by the contractors. It does not need any experience from the user and runs the modeling very fast. This is an advantage when fast results are needed to plan the continuity of the drilling program. The greatest contribution of this work shows that the program developed by the Electromagnetic Interpretation Research Group of Universidade de Brasilia can achieve results very similar to the results from EM1DTM nine times faster, even though its quantitative result are not accurate. 
A new target, with the same signature of the deposit was found to the south of the main ore body. This target has few drill holes that have not intercepted mineralization, but the geophysical inversion results show it should be better investigated.

To improve mineral exploration success, there is an accepted need to increase the discovery space by exploring under cover and to greater depths, using 3D geological modeling supported by multiple geophysical data. The resistivity signature found for Cristalino can be used as guide or reference models to identify a number of localities in the subsurface with similar geophysical signature in the same geological environment as Cristalino Deposit. These locations could be considered as potential targets and are candidates for further exploration.

\section{ACKNOWLEDGEMENTS}

The authors thank Vale S.A. for granting the permission to use geophysical and geological data for academic purposes. The colleagues from Vale S.A. for all support during the research in the names of Fernando Greco, Fernando Matos, Benevides Aires, Cristiane Moura, and Cantidiano Freitas. And the colleagues from Universidade de Brasília: Amanda Almeida Rocha, Mário Paes de Almeida, and Giancarlo Takenaka. Reinhardt A. Fuck acknowledges CNPq research fellowship. Corrections and suggestions by Adalene Silva, Renato Cordani, and anonymous reviewers helped improve this paper.

\section{REFERENCES}

ALMEIDA FFM, BRITO NEVES BB \& FUCK R. 1981. Brazilian structural provinces: an introduction. Earth-Science Reviews, 17: 1-29.

DOCEGEO. 1988. Província Mineral de Carajás. Litoestratigrafia e principais depósitos minerais. In: Congresso Brasileiro de Geologia, 35., Belém: SBG, p. 11-54.

EATON PA \& HOHMANN GW. 1989. A rapid inversion technique for transient electromagnetic soundings. Physics of the Earth Planetary Interiors, 53: 384-404.

EMIT - ELECTROMAGNETIC IMAGING TECHNOLOGY. 2011. Maxwell - Industry Standard Geophysical EM Data Modeling. Available on: $<$ http://www.electromag.com.au/maxwell.php>. Access on: July 15, 2011.

FARQUHARSON CG. 2006. Background for Program "EM1DTM" Version 1.0, developed under the consortium research project: Time Domain Inversion and Modeling of electromagnetic Data. Geophysical Inversion Facility, Department of Earth \& Ocean Sciences, University of British Columbia (UBC - GIF), Vancouver, Canada.

FARQUHARSONCG \& OLDENBURG DW. 1998. Nonlinear inversion using general measures of data misfit and model structure. Geophysical
Journal International, 134: 213-227.

FRISCHKNECHT FC \& RAAB PV. 1984. Time domain electromagnetic soundings at the Nevada test site. Geophysics, 49: 981-992.

GRAINGER CJ, GROVES DI, TALLARICO FH \& FLETCHER IR. 2008. Metallogenesis of the Carajás Mineral Province, Southern Amazon Craton, Brazil: Varying styles of Archean through Paleoproterozoic to Neoproterozoic base- and precious-metal mineralization. Ore Geology Reviews, 33: 451-489.

GROVES DI, BIERLEIN FP, MEINERT LD \& HITZMAN MW. 2010. Iron Oxide Copper-Gold (IOCG) Deposits through Earth History: Implications for Origin, Lithospheric Setting, and Distinction from other Epigenetic Iron Oxide Deposits. Economic Geology, 105: 641-654.

HITZMAN MW. 2000. Iron Oxide-Cu-Au Deposits: What, Where, When and Why. In: PORTER TM (Ed.). Hydrothermal Iron Oxide Copper-Gold \& Related Deposits: A Global Perspective. Adelaide, v. 1, p. 9-25.

HUHN SR, SANTOS AB, AMARAL AF, LEDSHAM EJ, GOUGÊA JL \& MARTINS LP. 1988. 0 terreno "granito greenstone" da região de Rio Maria - Sul do Pará. In: Congresso Brasileiro de Geologia, 35., Belém: SBG, v. 3, p. 1438-1452.

HUHN SR, SOUZA CI, ALBUQUERQUE MC, LEAL ED \& BRUSTOLIN V. 1999. Descoberta do depósito Cu(Au) Cristalino: geologia e mineralização associada - Região da Serra do Rabo-Carajás - PA. In: Simpósio de Geologia da Amazônia, 6., Manaus, p. 140-143.

NCL BRASIL. 2005. Revision de La Estimación de Recursos del Proyecto Cristalino. Vale S.A. Internal Report, 103 pp.

OLDENBURG DW \& LI Y. 2007. Inversion for Applied Geophysics: A Tutorial. Available on:

$<$ http://www.eos.ubc.ca/ubcgif/iag/tutorials/tutorial-v9.pdf >. Access on: January 10, 2011.

PINHEIRO RVL. 2000. Relatório de Consultoria Técnica. Projeto Cristalino - Serra dos Carajás/PA. Vale S.A. Internal Report, 52 pp.

SANDBERG SK. 1988. Microcomputer software for the processing and forward modeling of transient electromagnetic data taken in the central loop sounding configuration: New Jersey Geological Survey Open-File Report 88-1.

SMITH R. 2002. Geophysics of Iron Oxide Copper-Gold Deposits. In: PORTER TM (Ed.). Hydrothermal Iron Oxide Copper-Gold \& Related Deposits: A Global Perspective. Adelaide: PGC Publishing, v. 2, p. 357367.

TRAVAGLIA FILHO UJ. 2012. Desenvolvimento e implementação de software para obtenção da resistividade pela profundidade de dados TDEM. Master Dissertation no. 28, Instituto de Geociências - Universidade de Brasília - UnB, 102 pp.

VALE S.A. 2004. Relatório de reavaliação de reservas estudo de préviabilidade - Projeto Cristalino. Vale S.A. Internal Report, 164 pp. 
VON HUELSEN MGV. 2007. Interpretação de Dados de Eletromagnetometria Aeroeletrotransportada (AEM) do Sistema GEOTEM (Domínio do Tempo). Doctoral Thesis no. 80, Instituto de Geociências - Universidade de Brasília - UnB, 202 pp.

Recebido em 3 setembro, 2013 / Aceito em 3 abril, 2014

Received on September 3, 2013 / Accepted on April 3, 2014

\section{NOTES ABOUT THE AUTHORS}

Aline Tavares Melo. Graduated in Geology from Universidade de Brasília (2008) and Masters Degree in Applied Geophysics from the same university (2012). Worked as a geophysicist/geologist on the Mineral Exploration Team of the mining company Vale S.A. Currently, is a professor of Geophysics in the Department of Geology at the Institute of Geosciences of the Universidade Federal de Minas Gerais (UFMG). Has experience in Geosciences with an emphasis on Geophysics, acting on the following subjects: applied geophysics, geophysical inversion and mineral prospecting.

Mônica Giannoccaro Von Huelsen. Graduated in Geophysics from the Universidade de São Paulo (1990), M.Sc. in Geophysics from the Universidade de São Paulo (1993) and a Ph.D. in Geology from the Universidade de Brasília (2007). Worked as a consultant of the Hgeo/Intergeo Group (2005-2007). Currently, is a professor at the Universidade de Brasilia and the head of Seismological Observatory. Has experience in Geosciences with an emphasis on Applied Geophysics, acting on the following topics: electromagnetics, magnetics, gravimetry and seismology.

Umberto José Travaglia Filho. Graduated in Physics from the Universidade Católica de Brasilia (2005), M.Sc. in Applied Geosciences in the area of Geophysics (2012). Has experience in the area of Physics, with an emphasis on Geophysics, acting on the following subjects: electromagnetic methods in the time domain, seismology, infrasound with an emphasis on Applied Physics.

Reinhardt A. Fuck. Graduated in Geology from Universidade Federal do Rio Grande do Sul (1963) and a Ph.D. in Geology from Universidade de São Paulo (1972). Professor (retired) and Professor Emeritus at the Universidade de Brasilia, where currently is associate researcher. Has experience in Geosciences with an emphasis on Regional Geology, acting on the following topics: Neoproterozoic Tocantins Province, Brasília Belt (basement, magmatic arc), Borborema Province structure of the crust and lithosphere. 